\title{
Internal Control and Revenue Fund Management among County Governments in Kenya
}

\author{
Cleophas Omariba Oyaro \\ School of Business, University of Nairobi \\ University Way, P.O Box 30197-00100 \\ E-mail: cleophasoyaro@gmail.com \\ Orina Ronald Angwenyi (Corresponding author) \\ College of Human Resource Development \\ Jomo Kenyatta University of Agriculture and Technology, Kenya \\ E-mail: ronangwe@yahoo.com
}

Received: April 16, 2016 Accepted: June 11, 2016 Published: July 15, 2016

doi:10.5296/ijafr.v6i1.9746 URL: http://dx.doi.org/10.5296/ijafr.v6i1. 9746

\begin{abstract}
Informed by the auditor general's report of 2014 in which massive frauds and misuse of the revenue fund across counties in Kenya were reported, the study sought to establish the link between internal control and revenue fund management. The study adopted components of the Committee of Sponsoring Organizations of the Treadway Commission 2013 framework in its conceptualization. The study arrived at mixed results in terms of the relationship and nature of association between the components and revenue fund management. In addition, the study did not provide enough evidence to believe whether or not there existed significant differences in internal control among county governments in Kenya. This alluded to inconsistencies in implementation of internal control among the devolved units. Lastly, the study indicated that even if the framework has been successful in implementation of internal control among listed companies in the United States, the same framework cannot be effectively used in implementation of internal control in the context of a devolved system of government such as is in Kenya.
\end{abstract}

Keywords: Control environment, Risk assessment, Control activities, Information and communication, Monitoring activities, Revenue fund management 


\section{Mll Macrothink}

\section{Introduction}

\subsection{Background Information}

Internal Control has become an important debatable topic in all organizations due to latest financial crises which spread all over the world (Stefanescu, 2011). Internal control issues are very important to assure the accuracy, timeliness and reliability of the financial reports to the organizations (Holsapple et.al.2001). Attention to internal controls has significantly increased because of regulatory and competitive forces since 1990s. According to Brewer \& List (2005), the objective of internal control is to get work done efficiently and effectively without the wastage of economic resources. Common objectives of internal control include: reliability of financial reporting; effectiveness and efficiency of operations and compliance with applicable laws and regulation (American institute of Certified Public Accountants, 1996).According to State Bank of Pakistan (2004), objectives of internal control can be categorized into: performance objectives; information objectives and compliance objectives.

The performance objectives should focus on protection of assets, efficiency in the operation and risk management. The information objective requires accuracy of records and adequacy of disclosure. Compliance objective requires ensuring that laws, regulations and internal polices relevant to the organization are properly implemented. Brown (1962) points out that if the system of internal control is adequate the probability that fraud or other errors exist is remote. Internal control plays an important role in preventing and minimizing the occurrence of errors and fraud. According to Hayes et al., (2005) internal control comprises five components; the control environment, the entity's risk assessment process, the information and communication systems, control activities and the monitoring of controls.

\subsection{Problem Statement}

The severity of high-profile corporate accounting failure which has increased steadily over the last decade has led to development of new legislations, standards, codes and guidelines (IFAC, 2006). An effective internal control system is desired to ensure compliance with all of these and also to contribute to the safeguarding of assets, including the prevention and detection of fraud (ACCA, 2010). Internal control is desired to provide some assurance to stakeholders that scarce resources are not diverted away from basic considerations inherent in financial management system design (Lee, Johnson \& Joyce, 2004). Salawu and Agbeja (2007) examined auditing and accountability mechanism in the public sector and provided a significant contribution towards the need for a strong internal control. IFAC (2006); Lee, Johnson and Joyce (2004); Omolehinwa (2003) share a core principle that good governance by its nature, demands effective systems of internal control.

Internal control activities are the policies and procedures that help ensure that management directives are carried out (Walters \& Dunn, 2001). Control of the financial decisions covers the organization, method, process and internal audit established by the administration in order to ensure that the activities are carried out in compliance with the purpose of the administration and determined policies and legislation, and that assets and resources are protected, accounting records kept in an accurate and complete manner and financial and 


\section{Macrothink \\ International Journal of Accounting and Financial Reporting \\ ISSN 2162-3082 \\ 2016, Vol. 6, No. 1}

management information produced in line and reliable manner.

Public sector organizations deal with large amounts of public funds and operate in a largely political environment, thereby necessitating a need for a high degree of accountability in the way in which their financial affairs are being conducted (Prowle, 2010). Furthermore, all other aspects of finance management in the public sector should be done prudently. According to Rosen and Gayer (2010) these feelings towards government are inextricably bound up with its taxing and spending activities as county governments in Kenya are mandated by the constitution of Kenya(2010) to levy tax to add to the 15 percent of the equitable share they receive from the national government, which fund is supposed to be prudently utilized.

In spite of this, the Kenya auditor general's report (2014) unearthed frauds and misuse of resources from the devolved revenue fund in several counties across the country. These frauds and misuse brought to focus whether or not the fund was prudently being utilized and to whether or not the existing internal control mechanisms were adequate. The main focus of the study was then to establish the link between internal control and devolved revenue fund management. This was aimed at providing empirical evidence necessary to inform policy interventions, to seal loopholes leading to such frauds and misuse but within the context of a devolved system of government.

\subsection{Specific objectives}

The specific objectives included:

i. Establishing the observed statistical significance between internal control dimensions and revenue fund management among county governments in Kenya

ii. Examining the strength of association between internal control dimensions and revenue fund management among county governments in Kenya

iii. Finding out whether there are significant differences in internal control among counties in Kenya

iv. Finding out the effectiveness of the Committee of Sponsoring Organizations (COSO) framework in implementation of internal controls among county governments in Kenya

\subsection{Research Questions}

i. What is the observed statistical significance between internal control dimensions and revenue fund management among county governments in Kenya?

ii. What is the strength of association between internal control dimensions and revenue fund management among county governments in Kenya?

iii. Do significant differences in internal control exist among county governments in Kenya?

iv. What is the effectiveness of the COSO framework in implementation of internal controls among county governments in Kenya? 


\section{Macrothink \\ International Journal of Accounting and Financial Reporting \\ ISSN 2162-3082 \\ 2016, Vol. 6, No. 1}

\section{Literature Review}

\subsection{Theoretical Review}

\subsubsection{Internal Control}

Internal control refers to the organisation, policies and procedures used to help ensure that government programmes achieve their intended results. It helps to ensure that the resources used to deliver these programmes are consistent with the stated aims and objectives of the organizations concerned and that the programmes are protected from waste, fraud and mismanagement. Internal control helps ensure that reliable and timely information is obtained, maintained, reported and used for decision-making (SIGMA, 1996). In general, internal control describes the systems, processes and methods of managing activities rather than a specific unit in a ministry or government agency. The major components of internal controls are control environment, accounting system and control procedures (Harvey and Brown, 1998). According to Grieves (2000) internal control system available to a firm consists of: management oversight and the control culture; risk recognition and assessment; control of activities and segregation of duties; information and communication and monitoring activities and correcting deficiencies. Robbins (1982) defines internal control systems as the whole system of controls, financial and otherwise, established by management in order to carry out the business of the enterprise in an orderly and efficient manner, ensure adherence to management, safeguard the assets and secure as far as possible the completeness and accuracy of the records. According to Khan (1994), internal controls are designed to protect an institution from loss or misuse of its assets.

Internal control requires a strong control environment as well as a coherent framework of control systems and procedures. The control environment includes management's philosophy and operating style, the assignment of responsibility and the policing of internal control systems and procedures. Internal control involves thorough assessment of the risks facing the organisation and an identification of useful controls to manage those risks. In a complex organization, this can be a difficult task and one for which the leadership of the entity may wish to seek expert assistance. Internal and external auditors are frequently the source of such assistance (Magaisa, 2004). Because of the importance of internal controls in assuring the effective control of public funds and the proper execution of the budget, the budget department of the ministry of finance in many governments plays an active role in strengthening the management controls of the operating units (McNally, 2013). Managers should recognize that subordinates perform better if they have a clear understanding of the mission and goals of the organization and the purpose being served by the activities they are asked to perform. Channels of communication are part of the management control system. For example, managers should communicate their performance expectations to subordinates, who should then define the expectations for their components of the organization that are needed to accomplish the overall goals of the organization. It is important that communications flow upward as well as downward (McNally, 2013). 


\section{MInstitute Macrothink $_{\text {Int }}^{\text {Intis }}$}

International Journal of Accounting and Financial Reporting ISSN 2162-3082 2016, Vol. 6, No. 1

Internal controls also require the performance of control activities. The notion of control activities is common also under other names such as policies and procedures for segregation of duties, proper authorization of activities, taking information in documents, accounting physical checks on the account assets and documents. (Danescu, 2007), "specific devices" (Renard, 2002), "internal control mechanisms" (Arens, 2003) "procedures, internal control mechanisms and devices" (Oprean et.al, 2007)," internal control devices and instruments, policies and procedures that support performance management instructions (Morariu, et.al, 2008) and so forth.

\subsubsection{Fund Management}

Fund management is a very important component of corporate finance because it directly affects the liquidity, profitability and growth of a firm. It is important to the financial health of firms of all sizes as the amounts invested in working capital are often high in proportion to the total assets employed (Atrill, 2006). It involves the planning and controlling of current assets and liabilities in a manner that eliminates the risk of inability to meet short-term obligations and avoid excessive investments in these assets (Lamberson, 2005). This management of short-term assets is as important as the management of long-term financial assets, since it directly contributes to the maximization of projects' profitability, liquidity and total financial performance. Consequently, projects can minimize risk and improve the overall financial performance by understanding the role and drivers of funds(Lamberson, 2005). In addition, as established by several researchers (Peel and Wilson 2000, Padachi, 2006, Kotut, 2003) efficient management of capital is pivotal to the health and performance of firms hence their view that firms should employ the use of efficient practices of fund management as a strategy of improving their value. The literature on working capital management practices identifies efficiency of cash management, efficiency of receivables management and efficiency of inventory management as determinants of financial performance model.

Fund management should be able to manage all amounts coming in as revenue, all monies going out as expenses and ensure that they are able to sustain each other. The expenses should not exceed what is being earned (Hany\&Maged, 2009). Once in practice, the budget can be adjusted to prevent an excess of expenditure over income. In order to achieve a balance, there may be need to borrow from elsewhere be it internally or externally. Money sourced from other departments or a reserve set aside for that purpose is internal. External borrowing constitutes funding from lenders like banks and other well established institutions that are in the business of lending. Alternatively, adjustments of expenditure priorities are an option (Kawira, 2013).

An institution should learn to use what they have and also make choices on the amount of risk they are willing to face. Efficient fund management keeps tabs on all aspects of usage and income. There should be a keen eye on where the money is spent and the justifications given on the expenditures (Coker \& Adams, 2012). The amounts coming in should also be of closely scrutinized to inform the manager about what he or she is to check on, recommend or keep a close eye on. Each fund area is allocated its own capital and each section of the 
organization should be clear on where money and resources will come from (Ebimobewei \& Kereotu, 2011).

When funds are received, allocation is made to each section in accordance to their needs and performance. The sections of the organization should provide a clear guide about how money is allocated. To realize how they are doing, a comparison should be made with what was planned and what actually took place (Glance, 2008). This means the budget and actual cash flow similarities and differences. The two should not differ much as that would mean that they are not fully utilizing resources or they are misusing what has been allocated; this sometimes causes funding shortfalls. Constant differences may mean that there may be need to adjust the budget (Kawira, 2013).

\subsection{Theoretical Framework}

Some theory and regulation that attempt to explain the relationship between the dimensions of this paper are fronted. They include agency theory and Sarbanes-Oxley Act of 2002. Their relevance and application to the study are explained.

\subsubsection{Agency Theory}

The 1976 article - Theory of the Firm: Managerial Behavior, Agency Costs and Ownership Structure by Jensen and Meckling helped establish agency theory as the dominant theoretical framework of the corporate governance literature, and position shareholders as the main stakeholder (Lan et al. 2010, Daily et al. 2003). The adoption of the agency logic increased during the $1980^{\prime} \mathrm{s}$ as companies started replacing the hitherto corporate logic of managerial capitalism with the perception of managers as agents of the shareholders (Zajac et al. 2004).Given the separation of ownership and control, and the diverging risk profiles of the participating parties (Eisenhardt 1989, Jensen 1989), it cannot be expected that risk-averse managers (agents) will act in the interest of risk-neutral shareholders (principals) as it may not be in the manager's self-interest to pursue shareholder wealth maximization (Bonazzi et. al. 2007, Lan et al. 2010, Demsetz et al. 1985). Jensen et al. (1985) argue that the three prominent problems with management that cause the conflict of interest are, 1) the choice of effort, 2) differential risk exposure, and 3) differential time horizon. The agency problem in separating ownership and control is therefore the assumed diverging goals of the - cooperating parties - the residual claimant and manager (Donaldson 1990, Hendrikse 2003).

In order to resolve agency and risk-sharing problems in principal-agent relationships, agency theory prescribes two formal (and ideal) types of management mechanisms to govern these relationships. One is outcome-based management mechanism where both principals and agents can observe outcomes, and the principals reward agents based on measured performance outcomes (Ekanayake, 1989). The outcome-based management mechanism emphasizes results regardless of how the agents achieve them (Choi \& Liker, 1995). The other management mechanism is behavior-based which when applied, principals can monitor agents' behaviors and efforts which otherwise are unknown to the principals. The behaviorbased management mechanism emphasizes tasks and activities in agents' processes that lead 
to the outcomes of the agents (Eisenhardt, 1989).However, a noted problem with performance based pay is that "dysfunctional behavioral responses where agents emphasize only those aspects of performance that are rewarded" is present (Prendergast 1999). As such, just as the principal may learn which incentives work the best, the agent learns which aspects of performance the principal is interested in and primarily seeks to optimize these exact aspects (Shapiro 2005, Brickley et al. 1994). The consequence becomes a system where everything is driven towards meeting measurable targets and not necessarily towards creating real value and growth (Porter 1992)

\subsubsection{Relevance and Application of Agency Theory}

Agency theory explains the importance of the relationship between the County government (Principal) and the County employees (Agent). County governments are responsible for the actions of their agents and thus must be able to come up with supervision and monitoring procedures to ensure that they do not suffer losses, material or reputation due to the actions of their agents. In concurrence with the theories, some unscrupulous agents deviate from compliance to laid governance procedures for their own interest. Through the use of agency theory in this study, the role of internal control in guiding the relationship between county governments and county employees is assessed. The theory helped in determining how county governments can use their internal control processes to seal loopholes against frauds and misuse of the revenue fund.

\subsubsection{Sarbanes-Oxley Act of 2002}

The introduction of the Sarbanes-Oxley Act of 2002 (SOX), as a response to well-publicized accounting scandals, requires all public companies to disclose internal controls over financial reporting. Such disclosures of internal control deficiencies became widely available for the first time following the Sarbanes-Oxley Act of 2002. Section 404 of this regulation requires management to document their firm's internal controls and assess their effectiveness (Feng et al., 2010). Specifically, Section 404 of SOX requires management of public companies to issue an internal control report in which they take responsibility for maintaining adequate internal control, and make assertions concerning their effectiveness. Lin and Wu (2006) and Shenkir and Walker (2006) explain that a sound internal control system rests on adequate and comprehensive analysis of enterprise-wide risks, and, in order to effectively comply with Section 404 of Sarbanes-Oxley (SOX), firms are advised to establish enterprise risk management (ERM). That is also the reason that COSO ERM (2004) expanded on COSO (1992) Internal Control Framework to provide a more robust and extensive focus on the broader subject of ERM. Besides the compliance with SOX, the implementation of ERM has already been documented to improve firm performance (Hoyt et al., 2006; and Nocco and Stulz, 2006).

\subsubsection{Relevance and Application of SOX to the Current Study}

The auditor general's report of 2014 unearthed massive frauds and misuse of the revenue fund among county governments in Kenya. Such frauds and misuse brought to the fore whether or not internal control to check against such frauds and misuse were in place. This 


\section{Macrothink}

International Journal of Accounting and Financial Reporting

ISSN 2162-3082

also brought to the fore whether or not such internal controls were effective. The current study assessed the effectiveness of internal control in revenue fund management among county governments in Kenya. Assessment of effectiveness of internal control in organizations is a requirement by SOX, thus its relevance to the study.

\subsection{Conceptualization}

The study adopted the COSO internal control integrated framework (2013) in its conceptualization. The model is used in ensuring Sarbanes Oxley Act (SOX) internal control compliance. The majority of U.S publicly traded companies have adopted the model to do this. The model is embedded on five components that were used as independent variables in this study. The components were: control environment, risk assessment, control activities, information and communication and monitoring activities. The dependent variable was revenue fund management among county governments in Kenya. Figure 1 illustrates the model.

\section{Figure 1: Conceptualization Framework}

Independent variables Dependent Variable

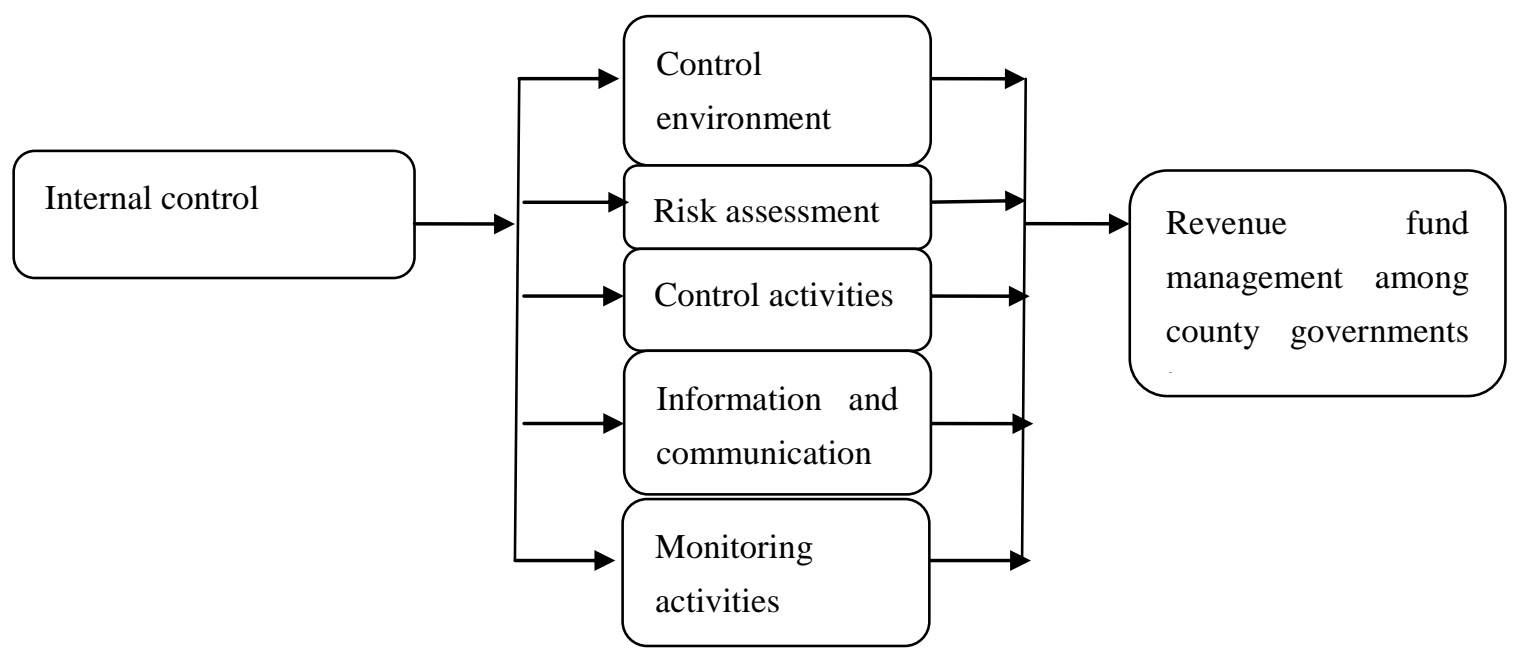

Source: Author, 2016 


\section{Macrothink

\section{Research Methodology}

\subsection{Introduction}

The section discussed the methodological aspects of the research including the research design, population of study, sampling procedures and sample size, data collection procedures, ethical considerations, data analysis and its decision criteria.

\subsection{Research Design}

Explanatory research design was used in undertaking this research. According to Young (1990) this is a comprehensive study of social unit, e.g. an individual, a group, social institution, district or a community. Efforts are made to study each and every aspect of the subject in minute details and then case data generalization and inferences are drawn (Leedy,2003).

Explanatory research design depends on the researchers' perception and gives a clearer insight because it is direct and not indirect and abstract in its approach. The researcher can obtain a real record of personal experiences which can reveal the subjects motivations that drive one to action along with the forces that direct to adoption of certain patterns of behaviour.

\subsection{Target Population}

Mugenda and Mugenda (2003) defines target population as the members of a real or hypothetical set of people to generalize results of the research. The target population of this study was 33,850 (MoD, 2016) employees from 8 out of 47 county governments in Kenya and selected one (1) each from the eight provinces in Kenya. But the employees that had characteristics to be measured included: internal auditors, finance officers, accountants and revenue officers working in respective counties. Their number was approximately3385 officers. Their categorization was as follows: 
Table 1: Target Population

\begin{tabular}{|l|l|l|l|}
\hline & Category & $\begin{array}{l}\text { Population } \\
\text { Frequency }\end{array}$ & Percentage \\
\hline 1 & Kisii & 382 & 11.3 \\
\hline 2 & Kakamega & 326 & 9.7 \\
\hline 3 & Nairobi & 1152 & 34.0 \\
\hline 4 & Kajiado & 321 & 9.5 \\
\hline 5 & Machakos & 333 & 9.8 \\
\hline 6 & TaitaTaveta & 311 & 9.3 \\
\hline 7 & Garissa & 208 & 6.2 \\
\hline 8 & Kiambu & 352 & 10.2 \\
\hline & Total & $\mathbf{3 , 3 8 5}$ & $\mathbf{1 0 0 . 0}$ \\
\hline
\end{tabular}

Source: Ministry of Devolution (2016).

\subsection{Sampling Design}

The sample of respondents was determined using the formula adopted from Mugenda and Mugenda (2003).

Thus: $\mathrm{n}=\mathrm{Z}^{2} \mathrm{pq} / \mathrm{d}^{2}$

Where by $\mathrm{n}=$ the desired sample size, $\mathrm{z}=$ the standard normal deviation at the desired confidence level, $\mathrm{p}=$ the proportion in the target population estimated to have characteristics being measured, $q=1-p, d=$ the level of statistical significance set.

The sample size for the study was estimated within $95 \%$ confidence interval $(\mathrm{z}=1.96)$ and a desired accuracy level of 0.05 as follows;

$\mathrm{n}=(1.96)^{2} \cdot(0.1) \cdot(0.9) /(0.05)^{2}=138$ (approx) 
For this research a total sample size of 138 was adequate. Since 138 was the total sample size required, this was picked as a proportion of 3,385 using stratified random sampling as follows;

Table 2: Sampling Design

\begin{tabular}{|l|l|l|l|l|}
\hline & Category & $\begin{array}{l}\text { Population } \\
\text { Frequency }\end{array}$ & Sample Ratio & Sample Size \\
\hline 1 & Kisii & 382 & 0.040 & 16 \\
\hline 2 & Kakamega & 326 & 0.040 & 13 \\
\hline 3 & Nairobi & 1152 & 0.040 & 46 \\
\hline 4 & Kajiado & 321 & 0.040 & 13 \\
\hline 5 & Machakos & 333 & 0.040 & 14 \\
\hline 6 & TaitaTaveta & 311 & 0.040 & 13 \\
\hline 7 & Garissa & 208 & 0.040 & 14 \\
\hline 8 & Kiambu & 352 & 0.040 & $\mathbf{1 3 8}$ \\
\hline & Total & & & 9 \\
\hline
\end{tabular}

Source: Author (2016)

\subsection{Data Collection Procedures}

The data collection procedures involved a number of steps. First, the researchers sought for a research permit in writing to conduct the study from the University of Nairobi. After the permission was granted, then the researchers recruited research assistants who were trained on how to conduct the data collection exercise. The researchers informed the respondents about the data collection exercise and after consultation agreed on the date of commencement. The respondents were visited at their respective Counties after being informed in advance about the data collection exercise.

Data for the study was collected using structured questionnaires which were delivered to the Counties by the Research Assistants. In order to increase the response rate, research assistants clarified any arising issues during the filling of questionnaires by the respondents.

\subsection{Data Analysis}

Quantitative methods were used to analyze the data collected. Quantitative methods permit 


\section{Mll Macrothink}

International Journal of Accounting and Financial Reporting

ISSN 2162-3082

2016, Vol. 6, No. 1

specification of dependent and independent variables and allows for longitudinal measures of subsequent performance of the research subject (Meyer et al., 1995). The data was cleaned and analyzed using inferential statistics.

Inferential statistics analysis always involve the process of sampling and the selection of a small group assumed to be related to the population from which it is drawn (Best \& Kahn, 2003).Inferential statistics is used to draw inferences about a given phenomenon in the population based on the results from a randomly selected sample, and to test hypothesis and enable the researcher generalize results from the sample of the population. Pearson product moment correlation analysis was used to establish the nature of association between variables and multiple regression analysis used to establish the observed statistical significance among independent variables. The regression equation estimate was in the form;

$y=\beta_{0}+\beta_{1} x_{1}+\beta_{2} x_{2}+\beta_{3} x_{3}+\beta_{4} x_{4}+\beta_{5} x_{5}+\varepsilon$

Where $\beta_{0}$ is the intercept, $\beta_{1}$ measures change in $Y$ with respect to $X_{1}$, holding other factors constant, $\beta_{2}$ measures the change in $Y$ with respect to $X_{2}$ holding other factors constant and $\beta_{3}$ measures the change in $\mathrm{Y}$ with respect to $\mathrm{X}_{3}$ holding other factors constant, where in this context $\mathrm{X}_{1}$ represented control environment, $\mathrm{X}_{2}$ represented risk assessment, $\mathrm{X}_{3}$ represented control activities, $\mathrm{X}_{4}$ represented information and communication and $\mathrm{X}_{5}$ represented monitoring activities.

\subsubsection{Decision criteria}

t-test was used to test for observed statistical significance of the independent variables. Any variable that had a probability value of less than $0.05(\mathrm{p} \leq 0.05)$ was taken to be statistically significant while a variable that had a probability value greater than $0.05(\mathrm{p} \geq 0.05)$ was taken to be statistically insignificant. Pearson product moment correlation coefficients were used to establish the strength of association between independent variables and the dependent variable. A variable that had a coefficient close to one $( \pm 1)$ was taken be strongly associated; a variable with a coefficient close to $0.5( \pm 0.5)$ was taken to be moderately associated while a variable that had a coefficient close to zero $( \pm 0.0)$ was taken to be marginally associated. A variable with a correlation coefficient of 0.00 was taken to have no association (zero association) with the dependent variable. F-test (ANOVA) was used to find out whether or not there were significant differences in internal control among counties under study. A probability value less than $0.05(\mathrm{p} \leq 0.05)$ depicted significant differences while a probability value greater than 0.05 ( $p \geq 0.05$ ) depicted lack of significant differences. The coefficient of determination $\mathrm{R}^{2}$ was used to find out the effectiveness of the COSO framework in implementation of internal control among county governments in Kenya. A determination coefficient less that $0.7\left(\mathrm{R}^{2} \leq 0.7\right)$ depicted that the COSO framework was statistically ineffective while a coefficient greater than $0.7\left(\mathrm{R}^{2} \geq 0.7\right)$ depicted that the COSO framework was statistically effective and could be used in implementing internal control in the context of devolved system of government to drastically reduce or end frauds and misuse in revenue fund management. 


\section{Macrothink \\ International Journal of Accounting and Financial Reporting \\ ISSN 2162-3082 \\ 2016, Vol. 6, No. 1}

\section{Findings and Interpretations}

\subsection{Findings}

On the observed statistical significance of the internal control dimensions, the study indicated that monitoring activities $(\mathrm{t}=2.232, \mathrm{p}=0.028)$ was significant and a good predictor of internal control in revenue fund management while risk assessment $(t=1.742, p=0.084)$ and information and communication $(\mathrm{t}=1.715, \mathrm{p}=0.089)$ were insignificant and poor predictors of internal control in revenue fund management among county governments in Kenya. Nonetheless, the study did not provide enough evidence on whether or not control environment $(\mathrm{t}=3.852, \mathrm{p}=0.000)$ and control activities $(\mathrm{t}=5.723, \mathrm{p}=0.000)$ were statistically significant or insignificant as their computed $\mathrm{p}$-values were both found to be zero $(\mathrm{p}=0.000)$. This is as shown in table 3 .

Table 3:Coefficients ${ }^{\mathrm{a}}$

\begin{tabular}{|c|c|c|c|c|c|c|}
\hline \multirow{2}{*}{\multicolumn{2}{|c|}{ Model }} & \multicolumn{2}{|c|}{$\begin{array}{l}\text { Unstandardized } \\
\text { Coefficients }\end{array}$} & \multirow{2}{*}{\begin{tabular}{|l} 
Standardized \\
Coefficients
\end{tabular}} & \multirow[b]{2}{*}{$t$} & \multirow[b]{2}{*}{ Sig. } \\
\hline & & $\mathrm{B}$ & Std. Error & & & \\
\hline 1 & (Constant) & .916 & .567 & & 1.616 & .109 \\
\hline & Control environment & .307 & .080 & .288 & 3.852 & .000 \\
\hline & Risk assessment & .157 & .090 & .134 & 1.742 & .084 \\
\hline & Control activities & .397 & .069 & .487 & 5.723 & .000 \\
\hline & $\begin{array}{l}\text { Information and } \\
\text { communication }\end{array}$ & 148 & .086 & .139 & 1.715 & .089 \\
\hline & Monitoring activities & -.206 & .092 & -.183 & 2.232 & .028 \\
\hline
\end{tabular}

a. Dependent Variable: Revenue fund management

On the strength of association between the internal control dimensions and revenue fund management, the study indicated that monitoring activities was strongly and positively associated $(r=0.013,0.887)$ with internal control in revenue fund management while control activities was moderately and positively associated $(r=0.503,0.000)$ with internal control in revenue fund management among county governments in Kenya. Control environment ( $\mathrm{r}=$ $0.303,0.001)$, risk assessment $(\mathrm{r}=0.241,0.008)$ and information and communication $(\mathrm{r}=$ $0.292,0.001$ ) were found to be weakly but positively associated with internal control in 
revenue fund management as shown in table 4.

Table 4: Correlations

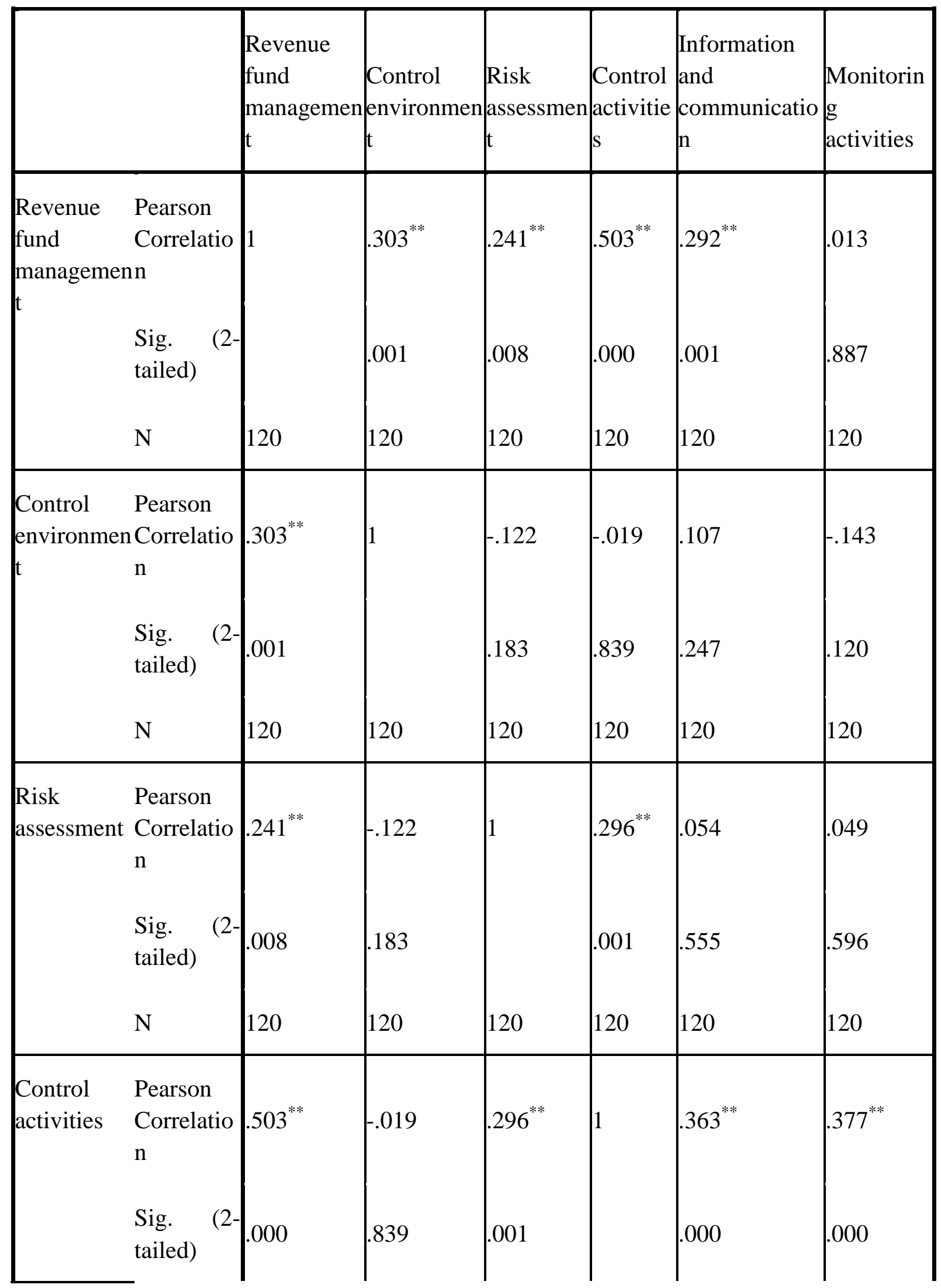




\begin{tabular}{|c|c|c|c|c|c|c|c|}
\hline & $\mathrm{N}$ & 120 & 120 & 120 & 120 & 120 & 120 \\
\hline & $\begin{array}{l}\text { Pearson } \\
\text { Correlatio } \\
\mathrm{n}\end{array}$ & $.292^{* *}$ & .107 & .054 & $.363^{* *}$ & 1 & $.337^{* * *}$ \\
\hline & $\begin{array}{l}\text { Sig. } \\
\text { tailed) }\end{array}$ & .001 & .247 & .555 & .000 & & .000 \\
\hline & $\mathrm{N}$ & 120 & 120 & 120 & 120 & 120 & 120 \\
\hline $\begin{array}{l}\text { Monitoring } \\
\text { activities }\end{array}$ & $\begin{array}{l}\text { Pearson } \\
\text { Correlatio } \\
\mathrm{n}\end{array}$ & .013 & -.143 & .049 & $.377^{* *}$ & $.337^{* * *}$ & 1 \\
\hline & $\begin{array}{l}\text { Sig. } \\
\text { tailed) }\end{array}$ & .887 & .120 & .596 & .000 & .000 & \\
\hline & $\mathrm{N}$ & 120 & 120 & 120 & 120 & 120 & 120 \\
\hline
\end{tabular}

**. Correlation is significant at the 0.01 level (2-tailed).

On whether or not there were significant differences among county governments relating to internal control in revenue fund management, the study did not provide enough evidence to believe either way as the computed analysis of variance value (F-test) for the study was found to be zero $(\mathrm{p}=0.000)$. Table 5 has the details.

Table 5: ANOVA ${ }^{\mathrm{a}}$

\begin{tabular}{|ll|l|l|l|l|l|}
\hline \multicolumn{2}{|l|}{ Model } & Sum of Squares & df & Mean Square & F & Sig. \\
\hline $1 \quad$ Regression & 33.556 & 5 & 6.711 & 15.373 & $.000^{\mathrm{b}}$ \\
\cline { 3 - 5 } & Residual & 49.769 & 114 & .437 & & \\
Total & 83.325 & 119 & & & \\
\hline
\end{tabular}

a. Dependent Variable: Revenue fund management 
b. Predictors: (Constant), Monitoring activities, Risk assessment, Control environment, Information and communication, Control activities

Finally, the coefficient of determination for the study was found to be 0.403 implying that the adopted COSO framework dimensions i.e. control environment, risk assessment, control activities, information and communication and monitoring activities only explained 40.3 percent variations in the internal control of the revenue fund. This further implied that the COSO framework was not effective and could not be used in implementation of internal controls among county governments in Kenya. See table 6 for the findings.

Table 6: Model Summary

\begin{tabular}{|l|l|l|l|l|}
\hline Model & \multirow{2}{*}{} & R Square & Adjusted R Square & $\begin{array}{l}\text { Std. Error of the } \\
\text { Estimate }\end{array}$ \\
\hline 1 & $.635^{\mathrm{a}}$ & .403 & .377 & .661 \\
\hline
\end{tabular}

a. Predictors: (Constant), Monitoring activities, Risk assessment, Control environment, Information and communication, Control activities

\subsection{Discussion}

The aim of the first and second objectives was to find out the relationship and nature of association between internal control dimensions and revenue fund management. The study provided no evidence to indicate whether or not control environment had neither significant nor insignificant relationship with revenue fund management. This contradicts the findings of McKendrick (2011) which indicated that organizations still experience significant control deficiencies in today's control environment. The study indicated that risk assessment had an insignificant weak positive association with revenue fund management. This contradicts the findings of Gunderson and Hachigian (2010) which reported a significant relationship between risk assessment and organization's progress towards its financial goals. The study did not provide enough evidence to believe whether or not control activities had neither a significant nor an insignificant relationship with revenue fund management. This as well contracts the findings by Poupart (2010) whose results reported a significant relationship between control activities and attainment of firm's objectives, part of which are financial in nature. The study also indicated that information and communication had an insignificant weak positive association with revenue fund management. This concurs with the findings of orina (2016) which found out that information and communication had an insignificant positive weak association with organization's financial growth. Nonetheless, the study found that monitoring activities had a significant strong positive association with revenue fund management. This contradicts the findings of orina (2016) which reported an insignificant positive weak association with financial growth.

On whether or not there existed significant differences in internal control in revenue fund 


\section{Mll Macrothink}

International Journal of Accounting and Financial Reporting ISSN 2162-3082 2016, Vol. 6, No. 1

management among county governments in Kenya, the study did not provide enough evidence to believe that there are or there are no such significant differences because the computed analysis of variance value was found to be zero. However, no results were found to neither support nor contradict the position of this study. Finally, the study indicated that the adopted COSO framework dimensions i.e. control environment, risk assessment, control activities, information and communication and monitoring activities only explained 40.3 percent variations in the internal control of the revenue fund. This implied that the COSO framework was not effective and could not be used in implementation of internal control among county governments in Kenya. No study as well was found to neither support nor contract this position.

\subsection{Conclusions}

Since the study adopted the COSO internal control integrated framework of 2013 in its conceptualization, it would be assumed that for the framework to be effectively used in implementation of internal control in any form of organization, its five components namely control environment, risk assessment, control activities, information and communication and monitoring activities are supposed to have significant relationships and strong associations with internal control. But this study arrived at mixed results. In addition, the study did not provide enough evidence to believe whether or not there existed significant differences in internal control among county governments in Kenya. This alluded to inconsistencies in implementation of internal control in the devolved units. Lastly, the study provided evidence to indicate that the adopted framework even if it has been successful in implementation of internal control among listed companies in the United States, the same framework cannot be effectively used in implementation of internal control in revenue fund management in the context of a devolved system of government such as is in Kenya. Consequently, to establish such a framework that can be used effectively in implementation of internal control within a devolved system of government, the study recommended further research.

\subsection{Acknowledgement}

Owing to successful completion of this paper, we would like to thank Dr.Maurice Sakwa and Dr. Kabare Karanja for their varying contributions. We are also grateful to the librarians at Amref-Africa International Training Centre Resource Centre and those of the Kenya National Bureau of Statistics who assisted us in tracing useful materials for the study. We would also like to thank our families and friends who contributed directly or indirectly to the success of this paper. Finally, we would like to thank the almighty God for seeing us this far.

\section{References}

ACCA, (2010). Advanced Audit and Assurance. Kaplan Publishing.

American Institute of Certified Public Accountants (AICPA) (1996). Statement on Auditing Standards (SAS) No. 70, Service Organizations. 


\section{Macrothink}

International Journal of Accounting and Financial Reporting ISSN 2162-3082 2016, Vol. 6, No. 1

Arens, L. (2003). Audit - An Integrated Approach, the $8^{\text {th }}$ Edition, Publishing House ARC, Chisinau, pp 332.

Atrill, P. and McLaney, E. (2006). Management Accounting for Decision Makers. $6^{\text {th }}$ edition.

Best J. W., and Kahn, J.V. (2003). Research in Education, ( $9^{\text {th }}$ Ed). Boston: Allyn and Bacon.

Bonazzi, L. and Islam, S. (2007). Agency Theory and Corporate Governance: A Study of the Effectiveness of Board in their Monitoring of the CEO, Journal of Modeling in Management, 2, 1, pp. 7-23.

Brewer, P.R. (2005). International Trust. Entry in Polling America: An Encyclopedia of Public Opinion (Samuel J. Best and Benjamin Radcliff, Editors). Westport, CT: Greenwood Press.

Brickley, J., Smith, C. and Zimmerman, J. (1994). Ethics, Incentives, and Organizational Design, Journal of Applied Corporate Finance, 7, 2, pp. 20-30.

Brown, R. (1962). Changing Audit Objectives and Techniques. The Accounting Review, 37(4), 696-703.

Choi, T. and Liker, J. (1995). Bringing Japanese Continuous Improvement Approaches to US Manufacturing: The Roles of Process Orientation and Communications. Decision Sciences, 26, 589-620.

Coker, M.A. and Adams, J.A. (2012). Challenges of Managing Local Government Finance in Nigeria. Research on Humanities and Social Sciences. www.iiste.org ISSN 2224-5766 (Paper) ISSN 2225-0484 (Online), 2(3).

Daily, C., Dalton, D. and Cannella, Jr., A., (2003). Corporate Governance: Decades of Dialogue and Data, Academy of Management Review, 28, 3, pp.371-382.

Danescu, T. (2007). Financial Audit - Convergences between Theory and Practice, Irecson Publishing House, pp. 230-284.

Donaldson, L. (1990). The Ethereal Hand: Organizational Economics and Management Theory, (ed). Englewood Cliffs, J.J.: Prentice-Hall.

Ebimobewei, A. (2010). Determinants and Consequences of Internal Control in Firms: A Contingency Theory Based Analysis. J. ManagGov, 14, 115-144. Edition. New York: McGraw-Hill.

Eisenhardt, (1989). Building Theories from Case study Research. Academy of Management Review, 14: 532-550.

Ekanayake, S. (1988). A Stakeholder Theory of the Modern Corporation: Kantian Capitalism, in Beauchamps, T. and Werhane, P. H. (Eds). Ethical Issues in Business, Prentice-Hall, Englewood Cliffs, NJ. 166-171. 


\section{Macrothink}

International Journal of Accounting and Financial Reporting

ISSN 2162-3082 2016, Vol. 6, No. 1

Feng, M., Li, C. and McVay, S. (2010). Internal Control Management Guidance.

Glance, H.I. (2008). Effectiveness of Auditing for Proper Accountability in Nigerian Local Governments. Social Science Research Network.

Grieves, J. (2000). Introduction: The Origins of Organization Development, Journal of Management Development, Vol. 19, No. 5, p. 345.

Gunderson, D.S., and Hachigian, L.P. (2010). Analyzing, Managing and Disclosing Risk in the Emerging-Growth Company. New York/San Diego.

Hany, E. and Maged, A. (2009). Enterprise Resource Planning (ERP) Systems Implementation and Internal Audit Function Change.

Harvey, D.F., Brown, D.R. (1998). An Experiential Approach to Organization Development, $3^{\text {rd }}$ Edition, Prentice Hall, p. 68.

Hayes, R., Dassen, R., Schilder, A. and Wallage, P. (2005). Principles of Auditing. An Introduction to International Standards of Auditing, $2^{\text {nd }}$ edition, et. Pearson Education. Publisher.

Hendrikse, G. (2003). Economics and Management of Organizations, McGraw-Hill Education, New York, USA.

Holsapple, C. W. and Singh, M. (2001). The Knowledge Chain Model: Activity for Competitiveness, Expert Systems with Applications, Vol. 20, p 77-78.

Hoyt, R.E. D.L. Moore, and Liebenberg, A.P. (2006). The Value of Enterprise Risk Management: Evidence from the U.S. Insurance Industry, Working Paper.

International Federation of Accountants (IFAC), (2006). International Controls - A Review of Current Development. Pp 1-155.

Jensen, M. (1986). Agency Costs of Free Cash Flow, Corporate Finance and Takeovers.

Jensen, M. (1989). Eclipse of the Public Corporation. Harvard Business Review, 67(5):6.

Kawira, A. (2013). Strengthening Internal Audit Effectiveness. Indian Journal of Science and Technology, 5(5), 2777-2778.

Khan, M.Y. (1994). Financial Services, Tata McGraw hill Publishing Company Ltd., $3^{\text {rd }}$ Edition.

Kotut, S. (2007). Evaluating the Effectiveness of Auditing in Local Municipalities using Analytic Hierarchy Process: A General Model and the Israeli Example. International Journal of Auditing, 11, 187-210.

Lan, L. and Haracleous, L. (2010). Rethinking Agency Theory: The View from Law, Academy of Management Review, 35, 2, pp. 294-314.

Lee, R.D. Johnson, R.W. and Joyce, P.G. (2004). Public Budgeting Systems. USA. Jones and Barlett Publishers, USA. 


\section{MInstitute Macrothink $_{\text {Int }}$}

International Journal of Accounting and Financial Reporting ISSN 2162-3082 2016, Vol. 6, No. 1

Leedy, M.G., Lalonde, D. and Runk, K. (2003). Gender Equity in Mathematics: Beliefs of Students, Parents and Teachers. School Science and Mathematics, 103(6), 285-292.

Lin, H.H., and F.H., Wu (2006). How to Manage Section 404 of the Sarbanes-Oxley Act: What is Wrong with Section 404 of the Sarbanes-Oxley Act, Journal of Accounting and Corporate Governance, Vol. 3, No. 21 pp. 1-16.

Lumberson, M., Li, C. and McVay, S. (2005). Internal Control and Management Guidance. Journal of Accounting and Economics, 48, 190-209.

Magaisa, A.T. (2004). Corporate Governance and Banking, The Independent for January 16.

McKendrick, J. (2011). Moving to New ERP Environments: 2011 OAUG Governance, Risk and Compliance Best Practices Survey, Unisphere Research, February 2011.

McNally, J.S. (2013). One Approach to an Effective Transition. The 2013 COSO Framework \& SOX Compliance.

Meyer, B.D. (1995). Lessons from the U.S. Unemployment Insurance Experiments. Journal of Economic Literature, Vol. 33, No. 1 pp. 91-131.

Morariu, A., Suciu, G. and Stoian F., (2008). Internal Audit and Corporative Governance, Universitară Publishing House, Bucureşti, pp. 32-33.

Mugenda and Mugenda (2003). Research Methods: Acts Press, Nairobi.

Nocco, B.W., and R.M. Stulz, (2006). Enterprise Risk Management: Theory and Practice, Journal of Applied Corporate Finance, Vol. 18, No. 4 pp. 8-20.

Omolehinwa, E. (2005). Government Budgeting and Accounting in Nigeria. Lagos. Pumark Nigeria Limited.

Oprean, I. Popa, I.E. and Radu, D. (2007). Audit and Financial Control Procedures, Risoprint.

Orina, R.A. (2016). Agency Banking and Growth of Micro and Small Enterprises in Kenya. International Journal of Economics, Commerce and Management. Vol 4, Issue 4.

Padachi, D.G., James, K. and Joseph, M.M. (2006). Antecedents and Organizational Performance Implications of Internal Audit Effectiveness: Some Propositions and Research Agenda. Pacific Accounting Review, 22(3), 224-252.

Peel, A. and Wilson, J. (2000). Performance Auditing in Local Government: An Exploratory Study of Perceived Efficiency of Municipal Value for Money Auditing in Finland and Norway. The European Accounting Review, 10(3), 583-599.

Porter, M. E. (1992). Capital Disadvantage: America's Failing Capital Investment System, Harvard Business Review, 65-83.

Prendergast, C. (1999). The Provision of Incentives in Firms. Journal of Economic Literature, 37, 1, pp. 7-63. 


\section{Macrothink \\ International Journal of Accounting and Financial Reporting \\ ISSN 2162-3082 2016, Vol. 6, No. 1}

Prowle, M. (2013). Where now for Public Services? Presentation to CIPFA Conference 2013. Found at http://opinion.publicfinance.co.uk/2013/05/where-now-for-publicservices/Publishing House, ClujNapoca, pp. 42.

Renard, J. (1982). Internal Audit Theory and Practice, M.F.P. pp. 134-144.

Robbins, S. (1982). Essentials of Organizational Behaviour, $3^{\text {rd }}$ Edition, Prentice Hall, pp.14.

Rosen, H.S. and Gayer, T., (2013). Public Finance 46-48. $10^{\text {th }}$ ed.

Salawu, R.S., and Agbeja, O. (2007). Auditing and Accountability in the Public Sector. International Journal of Applied Economics and Finance, 1(1), 45-54.

Shapiro, S. (2005)._Agency Theory, Annual Review of Sociology, 31, 1, pp. 263-284.

Shenkir, W.G., and P.L., Walker (2006). Implementing Enterprise Risk Management, Statement on Management Accounting, Institute of Management Accountants.

Stefanescu, C. (2011). Corporate Governance. Concept in Accounting and Auditing Literature - An Overview "ante" and "post" Financial Crisis, Proceedings of $7^{\text {th }}$ International Conference on Management of Technological Changes 2011 (ISBN 978-96099486-3-0), pp. 749-752.

Walters, D. and Dunn, J. (2001). Student's Manual of Auditing, $6^{\text {th }}$ Edition, Thompson Learning, London pg 8:3.2-8:3.3.

Young, P. (1990). Progressive Taxation and Equal Sacrifice. American Economic Review 80, 253-266. 
APPENDIX I: QUESTIONNAIRE

\section{Serial No}

The questionnaire is meant to collect information on internal control and revenue fund management among county governments in Kenya. Kindly answer the questions by writing a brief statement or ticking in the boxes provided as will be applicable. The information provided will be treated as strictly confidential and at no instance will your name be mentioned in this research. This research is intended for an academic purpose only.

\section{SECTION ONE: DEMOGRAPHIC INFORMATION}

1. Name of County (Optional).

2. Gender Male $\square$ Female

3. Age below 30 years $\square$ 30-39 years $\square$ 40-49years $\square$ 50-59 years $\square$

4. For how long have you worked in your current position?

i. Less than one year $\square$ ii. Between 1-5 years

iii. Between 6-10 years $\square$ iv. Over 10 years

5. What is your highest level of education? (Please tick one)
i. Secondary
iii. Tertiary College
ii. Undergraduate
iv. Postgraduate
v. other (specify) 


\section{SECTION TWO: REVENUE FUND MANAGEMENT}

6. The following are statements about revenue fund management. To what extent do you agree with these statements? Guide: Strongly Disagree (1), Disagree (2), Neutral (3), Agree (4), Strongly Agree (5)

\begin{tabular}{|c|c|c|c|c|c|c|}
\hline No & Description & $\begin{array}{l}\text { Strongly } \\
\text { Disagree } \\
\text { (1) }\end{array}$ & $\begin{array}{l}\text { Disagree } \\
\text { (2) }\end{array}$ & $\begin{array}{l}\text { Neutral } \\
\text { (3) }\end{array}$ & $\begin{array}{l}\text { Agree } \\
\text { (4) }\end{array}$ & $\begin{array}{l}\text { Strongly } \\
\text { Agree (5) }\end{array}$ \\
\hline $\mathrm{i}$ & $\begin{array}{l}\text { The existing internal controls } \\
\text { minimize the risk of the revenue fund } \\
\text { against fraud }\end{array}$ & & & & & \\
\hline ii & $\begin{array}{l}\text { The existing internal controls } \\
\text { minimize the risk of the revenue fund } \\
\text { against wastage }\end{array}$ & & & & & \\
\hline iii & $\begin{array}{l}\text { The existing internal controls } \\
\text { minimize the risk of the revenue fund } \\
\text { against asset loss }\end{array}$ & & & & & \\
\hline iv & $\begin{array}{l}\text { The existing internal controls } \\
\text { improves the efficiency in cash } \\
\text { disbursements }\end{array}$ & & & & & \\
\hline $\mathrm{v}$ & $\begin{array}{l}\text { The existing internal controls } \\
\text { improves the efficiency in revenue } \\
\text { collection }\end{array}$ & & & & & \\
\hline vi & $\begin{array}{l}\text { The existing internal controls } \\
\text { improves the efficiency in inventory } \\
\text { management }\end{array}$ & & & & & \\
\hline vii & $\begin{array}{l}\text { The existing internal controls } \\
\text { improves the efficiency in receivables } \\
\text { management }\end{array}$ & & & & & \\
\hline viii & $\begin{array}{l}\text { The existing internal controls } \\
\text { strengthens liquidity of the fund }\end{array}$ & & & & & \\
\hline ix & $\begin{array}{l}\text { The existing internal controls } \\
\text { strengthens control of current assets }\end{array}$ & & & & & \\
\hline
\end{tabular}




\begin{tabular}{|l|l|l|l|l|l|l|}
\hline & and liabilities & & & & & \\
\hline $\mathrm{x}$ & $\begin{array}{l}\text { The existing internal controls } \\
\text { strengthens the fund's capacity to } \\
\text { borrow }\end{array}$ & & & & & \\
\hline
\end{tabular}

\section{SECTION THREE: CONTROL ENVIRONMENT}

7. Comment on control environment in revenue fund management. Guide: Strongly Disagree (1), Disagree (2), Neutral (3), Agree (4), Strongly Agree (5)

\begin{tabular}{|c|c|c|c|c|c|c|}
\hline No & Description & $\begin{array}{l}\text { Strongly } \\
\text { disagree } \\
\text { (1) }\end{array}$ & $\begin{array}{l}\text { Disagree } \\
\text { (2) }\end{array}$ & $\begin{array}{l}\text { Neutral } \\
\text { (3) }\end{array}$ & $\begin{array}{l}\text { Agree } \\
\text { (4) }\end{array}$ & $\begin{array}{l}\text { Strongly } \\
\text { agree (5) }\end{array}$ \\
\hline $\mathrm{i}$ & $\begin{array}{l}\text { The existing control environment } \\
\text { incorporates integrity and ethical } \\
\text { values in the fund management }\end{array}$ & & & & & \\
\hline ii & $\begin{array}{l}\text { The existing control environment } \\
\text { provides requisite standards, } \\
\text { processes and structures in the fund } \\
\text { management }\end{array}$ & & & & & \\
\hline iii & $\begin{array}{l}\text { The existing control environment } \\
\text { assigns specific authority and } \\
\text { responsibility in the fund } \\
\text { management }\end{array}$ & & & & & \\
\hline iv & $\begin{array}{l}\text { The existing control environment } \\
\text { provides for specific human resource } \\
\text { policies in the fund management }\end{array}$ & & & & & \\
\hline $\mathrm{v}$ & $\begin{array}{l}\text { The existing control environment } \\
\text { enforces accountability in the fund } \\
\text { management }\end{array}$ & & & & & \\
\hline vi & $\begin{array}{l}\text { The existing control environment } \\
\text { provides requisite management } \\
\text { philosophy and operating style in the } \\
\text { fund management }\end{array}$ & & & & & \\
\hline
\end{tabular}




\begin{tabular}{|l|l|l|l|l|l|}
\hline vii & $\begin{array}{l}\text { The existing control environment } \\
\text { provides oversight responsibility in } \\
\text { the fund management }\end{array}$ & & & & \\
\hline viii & $\begin{array}{l}\text { The existing control environment } \\
\text { provides a requisite audit committee } \\
\text { in the fund management }\end{array}$ & & & & \\
\hline
\end{tabular}

\section{SECTION FOUR: RISK ASSESSMENT}

8. Comment on risk assessment in revenue fund management. Guide: Strongly Disagree (1), Disagree (2), Neutral (3), Agree (4), Strongly Agree (5)

\begin{tabular}{|c|c|c|c|c|c|c|}
\hline No & Description & $\begin{array}{l}\text { Strongly } \\
\text { disagree(1) }\end{array}$ & $\begin{array}{l}\text { Disagree } \\
(2)\end{array}$ & $\begin{array}{l}\text { Neutral } \\
\text { (3) }\end{array}$ & $\begin{array}{l}\text { Agre } \\
\text { e (4) }\end{array}$ & $\begin{array}{l}\text { Strongly } \\
\text { agree (5) }\end{array}$ \\
\hline $\mathrm{i}$ & $\begin{array}{l}\text { The existing risk assessment } \\
\text { framework provides processes for risk } \\
\text { identification in the fund management }\end{array}$ & & & & & \\
\hline ii & $\begin{array}{l}\text { The existing risk assessment } \\
\text { framework provides processes for risk } \\
\text { analysis in the fund management }\end{array}$ & & & & & \\
\hline iii & $\begin{array}{l}\text { The existing risk assessment } \\
\text { framework provides processes for risk } \\
\text { response in the fund management }\end{array}$ & & & & & \\
\hline iv & $\begin{array}{l}\text { The existing risk assessment } \\
\text { framework provides limits for risk } \\
\text { tolerances in the fund management }\end{array}$ & & & & & \\
\hline $\mathrm{v}$ & $\begin{array}{l}\text { The existing risk assessment } \\
\text { framework provides means for } \\
\text { discussion of risk severity in the fund } \\
\text { management }\end{array}$ & & & & & \\
\hline vi & $\begin{array}{l}\text { The existing risk assessment } \\
\text { framework provides processes that } \\
\text { check for fraudulent financial } \\
\text { reporting in the fund management }\end{array}$ & & & & & \\
\hline
\end{tabular}




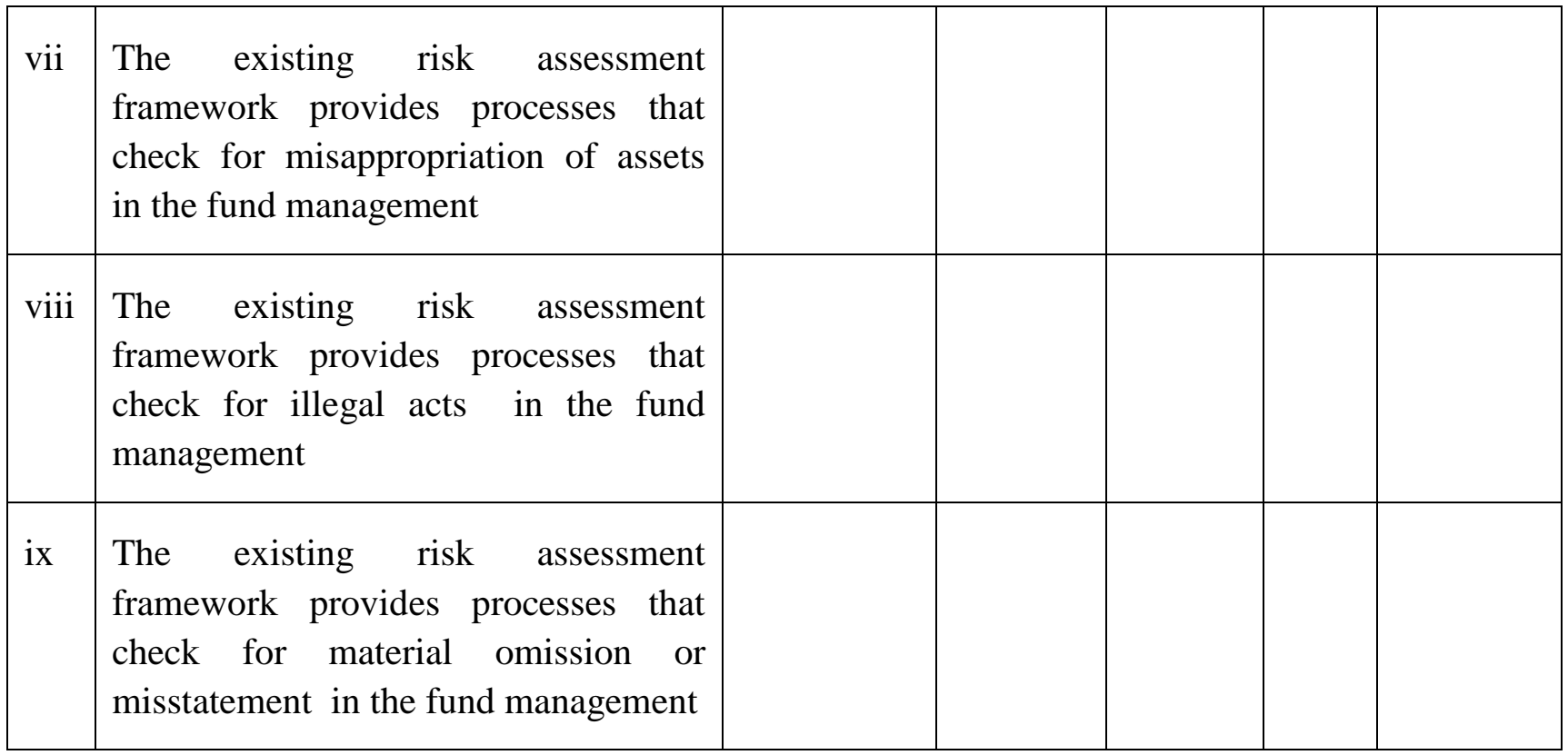

\section{SECTION FIVE: CONTROL ACTIVITIES}

9. Comment on control activities in revenue fund management. Guide: Strongly Disagree (1), Disagree (2), Neutral (3), Agree (4), Strongly Agree (5)

\begin{tabular}{|c|c|c|c|c|c|c|}
\hline & & $\begin{array}{l}\text { Strongly } \\
\text { disagree(1) }\end{array}$ & $\begin{array}{l}\text { Disagree } \\
(2)\end{array}$ & $\begin{array}{l}\text { Neutral } \\
\text { (3) }\end{array}$ & $\begin{array}{l}\text { Agree } \\
(4)\end{array}$ & $\begin{array}{l}\text { Strongly } \\
\text { agree (5) }\end{array}$ \\
\hline $\mathrm{i}$ & $\begin{array}{l}\text { The existing control activities } \\
\text { provide for development of } \\
\text { processes that contribute to } \\
\text { mitigation of risks in the fund } \\
\text { management }\end{array}$ & & & & & \\
\hline ii & $\begin{array}{l}\text { The existing control activities } \\
\text { provide for control activities over } \\
\text { technology in the fund management }\end{array}$ & & & & & \\
\hline iii & $\begin{array}{l}\text { The existing control activities } \\
\text { provide for deployment of control } \\
\text { activities through policies and } \\
\text { procedures in the fund management }\end{array}$ & & & & & \\
\hline iv & $\begin{array}{l}\text { The existing control activities } \\
\text { provide for performance reviews in } \\
\text { the fund management }\end{array}$ & & & & & \\
\hline
\end{tabular}




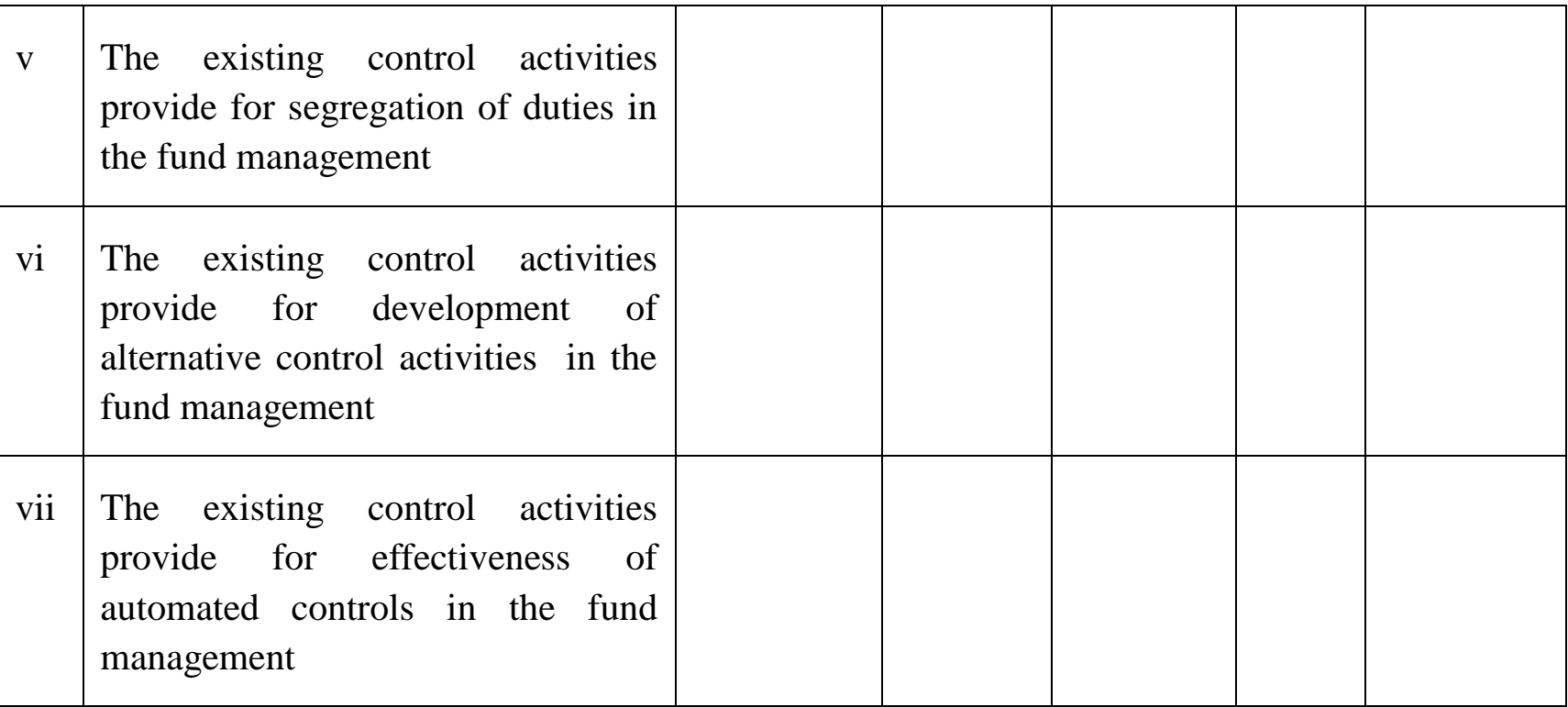

\section{SECTION SIX: INFORMATION AND COMMUNICATION}

10. Comment on information and communication in revenue fund management. Guide:

Strongly Disagree (1), Disagree (2), Neutral (3), Agree (4), Strongly Agree (5)

\begin{tabular}{|c|c|c|c|c|c|c|}
\hline No & Description & $\begin{array}{l}\text { Strongly } \\
\text { disagree } \\
\text { (1) }\end{array}$ & $\begin{array}{l}\text { Disagree } \\
\text { (2) }\end{array}$ & $\begin{array}{l}\text { Neutral } \\
\text { (3) }\end{array}$ & $\begin{array}{l}\text { Agree } \\
\text { (4) }\end{array}$ & $\begin{array}{l}\text { Strongly } \\
\text { agree (5) }\end{array}$ \\
\hline $\mathrm{i}$ & $\begin{array}{l}\text { The existing information and } \\
\text { communication provides for } \\
\text { consideration on how the } \\
\text { organization interacts with third } \\
\text { parties in the fund management }\end{array}$ & & & & & \\
\hline ii & $\begin{array}{l}\text { The existing information and } \\
\text { communication provides for means } \\
\text { of verification of source of } \\
\text { information in the fund management }\end{array}$ & & & & & \\
\hline iii & $\begin{array}{l}\text { The existing information and } \\
\text { communication provides for means } \\
\text { of retention of information used in } \\
\text { financial reporting in the fund } \\
\text { management }\end{array}$ & & & & & \\
\hline iv & $\begin{array}{l}\text { The existing information and } \\
\text { communication provides for means } \\
\text { of ensuring reliability and protection }\end{array}$ & & & & & \\
\hline
\end{tabular}




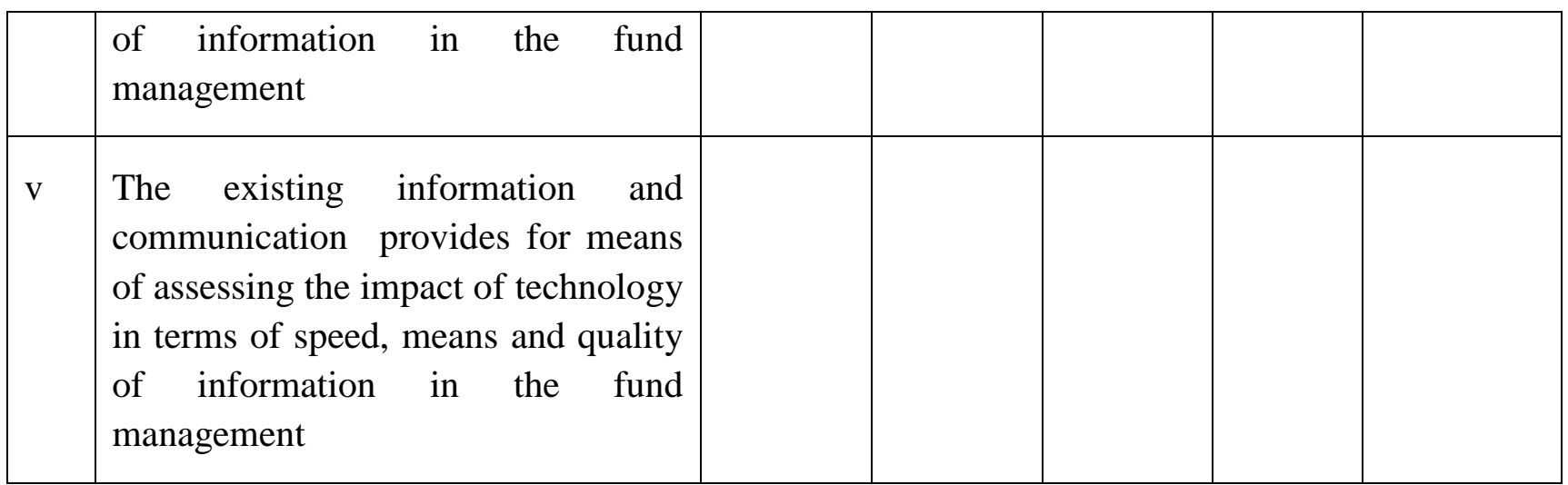

\section{SECTION SEVEN: MONITORING ACTIVITIES}

11. Comment on monitoring activities in revenue fund management. Guide: Strongly Disagree (1), Disagree (2), Neutral (3), Agree (4), Strongly Agree (5)

\begin{tabular}{|c|c|c|c|c|c|c|}
\hline & & $\begin{array}{l}\text { Strongly } \\
\text { disagree(1) }\end{array}$ & $\begin{array}{l}\text { Disagree } \\
(2)\end{array}$ & $\begin{array}{l}\text { Neutral } \\
\text { (3) }\end{array}$ & $\begin{array}{l}\text { Agree } \\
(4)\end{array}$ & $\begin{array}{l}\text { Strongly } \\
\text { agree (5) }\end{array}$ \\
\hline $\mathrm{i}$ & $\begin{array}{l}\text { The existing monitoring activities } \\
\text { provide for timely reporting of } \\
\text { deficiencies in the fund } \\
\text { management }\end{array}$ & & & & & \\
\hline $\mathrm{ii}$ & $\begin{array}{l}\text { The existing monitoring activities } \\
\text { provide for means of ascertaining } \\
\text { whether all internal control } \\
\text { components are present and } \\
\text { functioning in the fund management }\end{array}$ & & & & & \\
\hline iii & $\begin{array}{l}\text { The existing monitoring activities } \\
\text { provide for reporting of serious } \\
\text { matters to senior management in } \\
\text { the fund management }\end{array}$ & & & & & \\
\hline iii & $\begin{array}{l}\text { The existing monitoring activities } \\
\text { provide for means of addressing } \\
\text { effectiveness of internal control } \\
\text { components } \text { in the fund } \\
\text { management }\end{array}$ & & & & & \\
\hline iv & $\begin{array}{l}\text { The existing monitoring activities } \\
\text { provide means of building on-going } \\
\text { evaluation into routine operations }\end{array}$ & & & & & \\
\hline
\end{tabular}




\begin{tabular}{|l|l|l|l|l|l|l|}
\hline & in the fund management & & & & \\
\hline $\mathrm{v}$ & $\begin{array}{l}\text { The existing monitoring activities } \\
\text { provide for periodic separate } \\
\text { evaluations in the fund } \\
\text { management }\end{array}$ & & & & & \\
\hline
\end{tabular}

\section{Copyright Disclaimer}

Copyright for this article is retained by the author(s), with first publication rights granted to the journal.

This is an open-access article distributed under the terms and conditions of the Creative Commons Attribution license (http://creativecommons.org/licenses/by/3.0/). 